\title{
STRATEGI PENGEMBANGAN PRODUK DAN PENGENDALAIN MUTU DI PT.YAKULT INDONESIA PERSADA NIP MOJOKERTO
}

\author{
Muawanah \\ Institut Pesantren KH. Abdul Chalim Mojokerto \\ Email: anadarto54gmail.com
}

\begin{abstract}
Product development strategies and quality control are one of the keys to the company's succes in winning the market and achieving its goals. Company products are one of the important things and must continue to be developed so that business enterprises produce products that are acceptable to consumers. Quality is no less omportant than the product development strategy, to be improved in order to improve the quality of product. PT Yakult has a strategy to reach market share that can reach international markets, namely product development strategies and quality control.
\end{abstract}

Key Words: Product development strategies, quality control

\section{ABSTRAK}

Strategi pengembangan produk dan pengendalian mutu merupakan salah satu kunci sukses perusahaan untuk memenangkan pasar dan mencapai tujuannya. Produk perusahaan merupakan salah satu hal yang penting dan harus terus dikembangkan supaya usaha bisnis menghasilkan produk yang dapat diterima oleh konsumen.Mutu tidak kalah pentingnya dengan pengembangan produk untuk ditingkatkan dalam rangka meningkatkan kualitas dari produk. PT Yakult mempunyai strategi untuk mengapai pangsa pasar yang bisa menjangkau pasar internasional yaitu strategi pengembangan produk dan pengendalian mutu.

Kata Kunci: strategi pengembangan produk, pengendalian mutu

\section{PENDAHULUAN}

Yakult (Yakuruto) adalah minuman probiotik mirip yogurt yang dibuat dari fermentasi skimmed milk dan gula dengan bakteriLactobacillus casei. Karena L. casei Shirota dapat ditemui dalam sistem pencernaan, Yakult dipromosikan sebagai minuman yang baik untuk kesehatan. Minuman yang mengandung bakteri yang bermanfaat untuk menekan pertumbuhan bakteri jahat. Namanya berasal dari jahurto, bahasa Esperanto unt uk "yoghurt".

Yakult ditemukan oleh doktor Minoru Shirota pada 1930. Pada 1935, ia mendirikan Yakult Honsha Co., Ltd. (Kabushiki-gaisha Yakuruto Honsh) untuk memasarkan minuman ini. Sejak saat itu, Yakult telah memperkenalkan berbagai minuman yang mengandung bakteri Bifidobacterium breve, dan telah menggunakan lactobacilli untuk mengembangkan kosmetika. Yakult Honsha juga memainkan peran penting dalam penelitian obat kemotrapi irinotecan. 
Dalam mengembangkan perusahaan tentunya PT Yakult mempunyai strategi untuk mengapai pangsa pasar yang bisa menjangkau pasar internasional. yaitu strategi pengembangan produk dan pendendalian mutu .PT Yakult memproduksi dan menjual produknya diJepang, Asia, Australia, Amerika Latin, dan Eropa, walaupun bakterinya masih diimpor dari Jepang.

\section{STRATEGI PENGEMBANGAN PRODUK}

Pendapat para ahli mengenai pengertian pengembangan produk, seperti menurut Kotler dan Keller (2002:392) pengembangan produk adalah usaha perusahaan untuk meningkatkan penjualan dan pengembangan produk baru atau yang diperbaiki untuk pasar. Sedangkan definisi pengembangan produk menurut Fandy Tjiptono (2008:118) mengatakan pengertian produk baru meliputi produk orisinil, produk yang disempurnakan, produk yang dimodifikasi, dan merek baru yang dikembangkan melalui usaha riset dan pengembangan. Sejalan dengan Fandy Tjiptono, menurut Cannon dan Wichert dalam Buchari Alma (2002: 99) menyatakan bahwa pengembangan produk adalah pengembangan pada semua kegiatan yang dilakukan oleh pabrikan atau produsen dalam menentukan dan mengembangkan produknya, memperbaiki produk lama, memperbanyak keguanaan dari produk yang sudah ada dan mengurangi biaya produksi dan biaya pembungkus.

\section{PRODUK}

Beberapa ahli mendefinisikan produk dalam artian yang berbeda seperti menurut Philip Kotler dan Kevin Lane Keller (2007:4) menyatakan bahwa produk adalah segala sesuatu yang dapat ditawarkan ke pasar untuk memuaskan keinginan atau kebutuhan konsumen. Menurut Buchari Alma (2007: 139) produk ialah seperangkat atribut baik berwujud maupun tidak berwujud, termasuk didalamnya masalah warna, harga, nama baik pabrik, nama baik toko yang menjual (pengecer) dan pelayanan pabrik serta pelanggan pengecer, yang diterima oleh pembeli guna memuaskan keinginannya. Sedangkan definisi produk menurut Djaslim Saladin (2007:71), produk adalah segala sesuatu yang dapat ditawarkan ke pasar untuk mendapatkan perhatian, dibeli, 
dipergunakan, atau dikonsumsi dan yang dapat memuaskan keinginan dan kebutuhan konsumen.

\section{TAHAPAN PENGEMBANGAN PRODUK}

Tahapan yang perlu dijalani oleh perusahaan dalam melakukan proses pengembangan produk adalah ;

1. Gagasan produk : Pengembangan produk dimulai dengan pencarian ide / gagasan produk baru. Gagasan ini dating dari konsumen, tim penjualan, tim penelitian, dan bagian pengembangan.

2. Penyaringan : Tahap ini dirancang untuk menghilangkan gagasan yang tidak berhubungan dengan tujuan perusahaan, pada tahap ini diseleksi.perwakilan dari pemasaran,teknisi,dan produksi harus memberikan input pada tahap penyaringan.

3. Pengujian konsep : Seletah gagasan tersebut disaring perusahaan menguji riset pasar untuk mendapatkan input dari konsumen manfaat, harga yang sesuai dan cocok .

4. Analisis bisnis : Setelah mengumpulkan pendapat dari pasar/ konsumen maka harus melakukan pembandingan biaya produksi dan manfaat. Agar terlihat apakah produk yang dibuat tersebut memenuhi tujuan profitabilitas minimum atau tidak.

5. Pengembangan prototipe : Sewaktu perusahaan sudah menentukan potensi profitabilitas produk, bagian tekni katau riset dan pengembangan membentuk sebuah prototipe. Prototipe ini seperti produk contoh, prototipe ini dapa menjadi sangat mahal karena sering memerlukan peralatan dan pengembangan komponen ekstensif.

6. Pengujian produk dan uji pemasaran : Dengan menggunakan hal-hal yang dipelajari dari prototipe maka kemudian perusahaan menjalankan produksi yang terbatas.Lalu perusahaan dapat menguji produk tersebut untukmelihat apakah produk tersebut sudah memenuhi persyaratan kinerja apa belum.Jika sudah memenuhi persyaratan maka produk akan dijual pada daerah yang terbatas. 
Karena promosi dan saluran distribusi harusditetapkan untuk uji pasar, maka tahap ini cukup mahal biayanya.

7. Komersialisasi : Jika hasil uji pemasaran positif, perusahaan akan memulai produksi dan pemasaran berskala penuh.Komersialisasi yang bertahap, yang bertujuan menyebarkan produk baru tersebut ke daerah yang lebih luas, mencegah ketegangan yang semestinya tidak perlu terjadi pada kemampuan produksi awal. Demikian sebaliknya,keterlambatan dalam komersialisasi dapat memberikan kesempatan agi perusahaan lain untuk mengeluarkan produk yang dibuat untuk menjadi pesaing dengan produk baru tersebut (Griffin \& Ebbert, 2007).

8.

\section{MUTU PRODUK}

Kramer dan Twigg (1983) mendefinisikan mutu sebagai gabungan karakteristik atau atribut organoleptik yang memberikan identitas khusus suatu produk (warna, tekstur, rasa, atau flavor). Amerine et al (1965) menyatakan bahwa mutu merupakan karakteristik/keistimewaan menyeluruh suatu produk yang menunjukkan kemampuannya memenuhi kebutuhan.

ISO - 9000 mendefinisikan mutu sebagai derajat dari serangkaian karakteristik produk atau jasa yang memenuhi kebutuhan atau harapan yang dinyatakan atau diwajibkan (Suardi, 2001). ISO menambahkan kata diwajibkan untuk menitikberatkan bahwa mutu produk, selain bertujuan memenuhi keinginan konsumen, juga harus memperhatikan standar yang dibuat atau ditetapkan oleh negara.

Menurut definisi tersebut, mutu tidak ditentukan oleh satu at au dua karakteristik saja, tetapi merupakan gabungan keseluruhan karakteristik, termasuk karakteristik nonfungsional produk.

\section{KEUNGGULAN MUTU}

Perusahaan atau industri berupaya untuk membuat produk lebih unggul mutunya dibandingkan dengan pesaing. Keunggulan ini, misalnya, adalah rasa lebih enak, lebih renyah, lebih mudah penyajian, kemasan lebih mewah, dan sebagainya. Pada harga yang relatif sama, keunggulan mutu akan berdampak sangat besar pada penjualan meskipun 
keunggulan tersebut bersifat "kecil". Sebagai contoh, pada industry minuman AMDK (air minum dalam kemasan), adanya botol plastik yang kokoh,ukurannya sesuai,menarik dan disukai konsumen.

\section{METODE PENELITIAN}

Tipe penelitian yang digunakan adalah penelitian deskriptif kualitatif. Populasi dari penelitan ini adalah karyawan PT.Yakult Indonesia Persada NIP Mojokerto Teknik analisis data yang digunakan dalam penelitian ini menggunakan analisis cause effectvdan juga analisis compreration (membandingkan hasil temuan peneliti dengan teori yang digunakan).

\section{HASIL DAN PEMBAHASAN}

Perusahaan Yakult hanya menghasilkan minuman prebiotik dengan kandungan bakteri Lactobacillus casei Shirota strain lebih dari 6,5 milyar yang mampu mencapai usus dalam keadaan hidup. Dalam satu botol kemasan Yakult yang dijual di pasaran, terdiri dari komposisi sebagai berikut:

a. Lebih dari 6,5 milyar bakteri Lactobacillus casei Shirota strain

b. hidup

c. Susu bubuk skim

d. Glukosa dan sukrosa

e. Perisa Yakult

f. Air

Yakult tetap mempertahankan produk yang memiliki ciri khas warna alami dari hasil fermentasi tanpa tambahan rasa-rasa sintetis. Walaupun berbeda dalam cara pengemasan produk, Yakult selalu menjualnya dengan takaran yang pas untuk sekali minum dalam tiap kemasan botol $65 \mathrm{ml}$. Di beberapa negara yakult dijual dalam kemasan botol $100 \mathrm{ml}$.

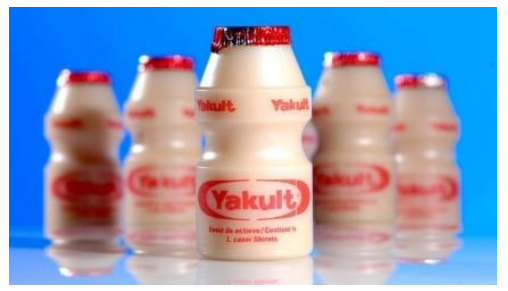

Gambar. Kemasan Produk Yakult Bakteri Lactobacillus Casei Shirota Strain 
Untuk mencegah penyakit yang banyak menyerang pencernaan, peran bakteri baik dalam usus perlu dimaksimalkan. Dari beberapa penelitian ditemukan bakteri asam laktat yang baik dan berguna bagi kesehatan. Bakteri itu dinamakan Lactobacillus casei. Ada beberapa manfaat bakteri ini bagi tubuh yaitu, bakteri ini mampu memproduksi asam laktat yang dapat meningkatkan jumlah bakteri baik dan menurunkan bakteri jahat, mencegah gangguan pencernaan terutama konstipasi dan diare serta mengaktifkan sel-sel kekebalan tubuh. Komposisi bakteri baik di perut yang ideal tak hanya melindungi tubuh dari diare dan sembelit, tetapi juga meningkatkan kekebalan tubuh, menurunkan kolesterol, dan mencegah kanker.

Lactobacillus casei merupakan bakteri probiotik yang telah lama digunakan dalam susu fermentasi seperti pada produk Yakult, Jepang. Lactobacillus casei membantu membatasi pertumbuhan bakteri jahat dalam usus. Lactobacillus casei adalah bakteri Gram-positif, anaerob, tidak memiliki alat gerak, tidak menghasilkan spora, berbentuk batang dan menjadi salah satu bakteri yang berperan penting. Lactobacillus adalah bakteri yang bisa memecah protein, karbohidrat, dan lemak dalam makanan, dan menolong penyerapan elemen penting dan nutrisi seperti mineral, asam amino, dan vitamin yang dibutuhkan manusia dan hewan untuk bertahan hidup.

Bakteri Lactobacillus casei yang terdapat atau digunakan dalam mengahasilkan produk probiotik yakult terbukti ampuh mengurangi terjadinya diare akut pada anakanak kecil dan perbedaannya signifikan secara statistik. Dalam penelitian probiotik, yang mengacu pada mikroorganisme hidup yang memberi keuntungan pada tuan rumah (konsumen) dengan memperbaiki keseimbangan flora usus. Strain probiotik adalah Lactobacillus casei strain Shirota (YIT9029), yang di samping aksi regulasi usus, telah dibuktikan yang memiliki aksi immunoregulatory seperti membantu menekan kambuhnya kanker kandung kemih dangkal dan mengurangi gejala alergi. 

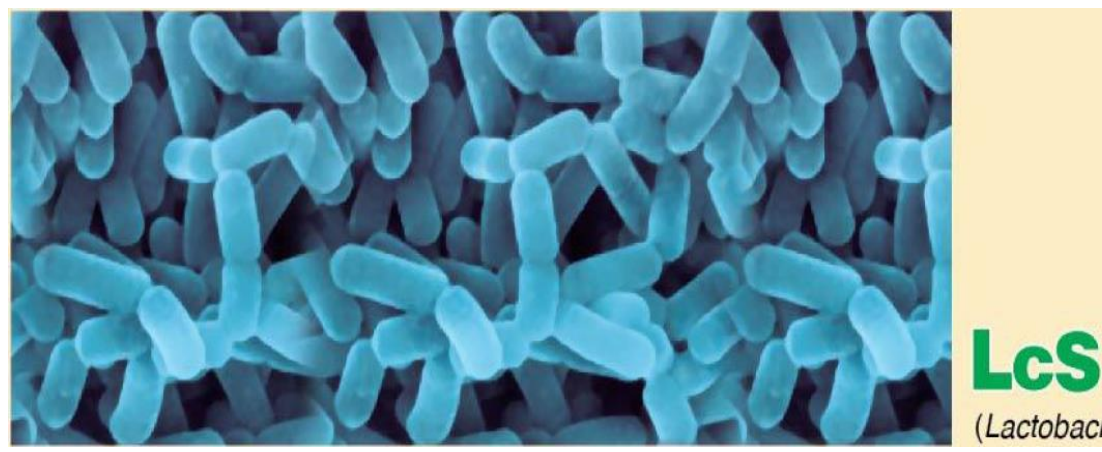

(Lactobacillus casei Shirota)

\section{STERILISASI YAKULT}

Suhu Danijel pemrosesan Ultra-Tinggi (sering Less)-perlakuan Panas ultra (disingkat keduanya UHT) adalah sterilisasi parsial USING makanandengan memberikan pemanasan untuk Artikel Yang waktu singkat, sekitar 1-2 Detik, Suhu PADA melebihi 135 oC (275 oF), Yang Suhu merupakan Yang diperlukan untuk Artikel membunuh spora dalam susu. UHT Produk Yang Umum adalah susu memucat, namun transovarial Suami juga digunakan untuk Artikel jus buah, Krim, yogurt, anggur, sup, rebusan Artikel Baru. susu UHT diciptakan PADA 1960-an dan Jaksa menjadi konsumsi umumnya tersedia untuk Artikel Di Tahun 1970-an. Panas Tinggi selama transovarial UHT dapat menyebabkan Maillard browning (ANTARA Kimia reaksi asam amino Dan Gula pereduksi, biasanya membutuhkan Panas) dan perubahan rasa susu Dan bau Produk.

\section{SUHU PENYIMPANAN YAKULT}

Yakult harus selalu disimpan pada suhu dibawah $10^{\circ} \mathrm{C}$ karena pada kondisi tersebut bakteri Yakult tidak aktif sehingga kualitas Yakult dapat dipertahankan terjaga. Penyimpanan pada suhu diatas $10^{\circ} \mathrm{C}$ akan mengakibatkan turunnya kualitas karena bakteri Yakult aktif, menghasilkan asam laktat yang menyebabkan Yakult menjadi asam dan jumlah bakteri hidupnya akan menurun.

\section{MUTU YAKULT}

PT Yakult Indonesia telah menerapkan proses produksi berdasarkan manajemen keamanan pangan sesuai standar ISO 22000:2005. Dalam manajemen kualitas, PT Yakult Indonesia juga telah mengantongi sertifikat internasional ISO 
9001:2008. Untuk itu tidak perlu diagukan produk Yakult yang sudah jelas aman dan bermutu unggul. Sertifikat tersebut bukan serta-merta diberikan. Sebagai bahan pertimbangan, maka yakult sebisa mungkin menerapkan standar untuk mengolah produknya. Cara-cara yang dilakukan harus bersifat higinies dan ramah lingkungan.

Tidak hanya bahan baku, standar prosedur operasi untuk karyawan juga sangat diperhatikan. Sebelum memasuki ruang kerja, sepatu yang dikenakan akan secara otomatis dibersihkan dengan alat. Karyawan harus memakai masker serta penutup kepala. Apabila karyawan telah mensucihamakan kedua tangan, barulah pintu ruang produksi bisa dibuka. Selain itu, karyawan harus melalui air shower yang berfungsi untuk membersihkan pakaian kerja khusus dari kotoran yang menempel.

Setelah karyawan siap dalam kondisi bersih, barulah mesinmesin produksi bisa dioperasikan. Pembuatan minuman prebiotik yakult harus melalui beberapa tahan seperti gambar di bawah ini:

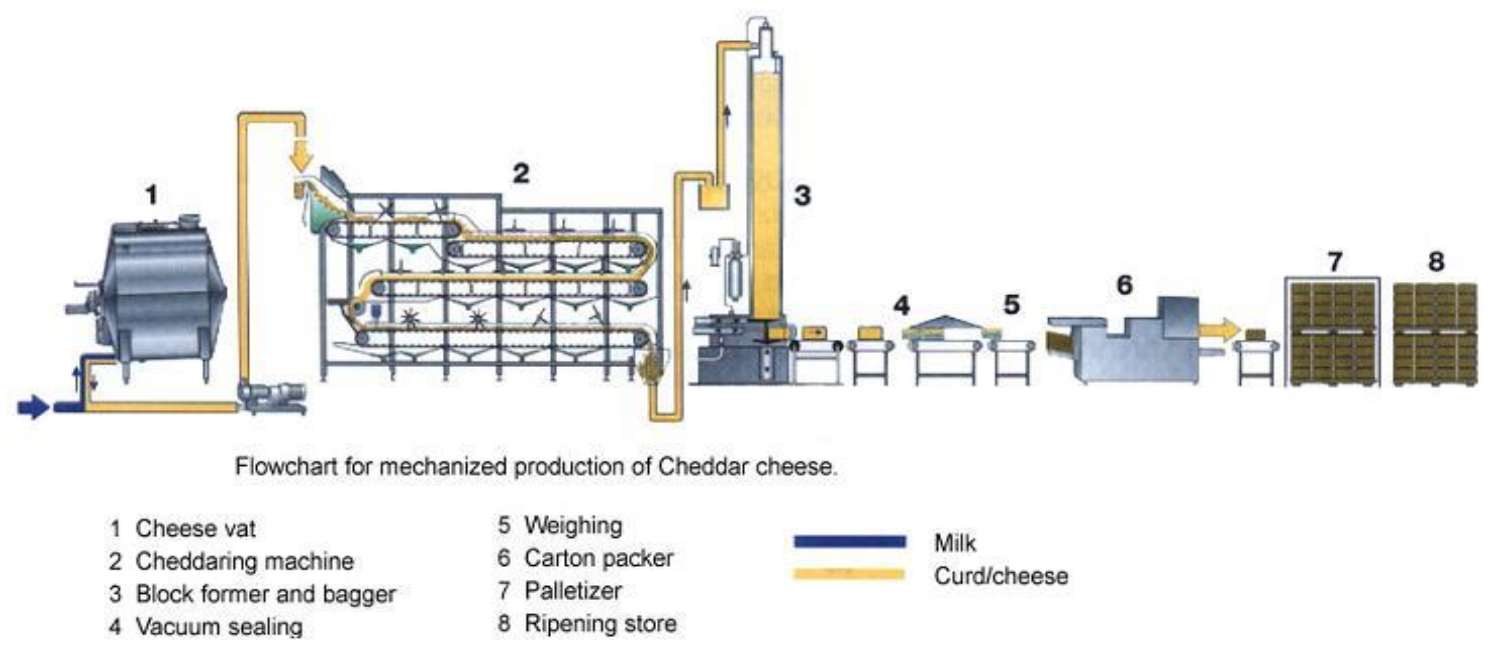

Gambar . Alur proses produksi

Pada gambar terdapat beberapa tahapan yang ditandai dengan huruf A-E dengan keterangan proses:

1. Proses pembuatan seed starter. Susu bubuk skim dan glukosa dilarutkan dengan air kemudian disterilisasi dan difermentasikan dengan penambahan Lactobacillus casei Shirota strain di dalam tangki pembibitan (Seed tank).

2. Proses pembuatan susu fermentasi. Dari seed tank, larutan dituangkan ke dalam silo. Larutan dari silo yang masih pekat selanjutnya dilarutkan dengan air panas 
di dalam dissolving tank. Setelah pelarutan sempurna, larutan ditransfer ke mesin Ultra High Temperature (UHT) untuk disterilisasi pada temperatur sekitar 120 C. Larutan susu steril akan ditransfer ke culture tank untuk mendapatkan warna khas yakult. Susu akan dipanaskan pada suhu $98 \mathrm{C}$. Setelah difermentasi hingga memenuhi standar mutu, larutan akan dihomogenisasi menggunakan mesin homogenier.

3. roses pembuatan sirup. Sukrosa akan dituang dalam silo tank. Sukrosa akan dilarutkan menggunakan air panas di dalam dissolving tank. Setelah larut sempurna, sirup ditransfer ke mesin HTST (High Temperature Short Time) untuk disterilisasi.

4. Proses mixing. Susu dari mesin homogenier dari proses B ditransfer ke storage tank yang sudah berisi sirup steril hasil proses C. Dari proses ini dihasilkanlah Yakult Concentrate (YACON).

5. Proses sterilisasi air pencampur. Air yang sudah mendapatkan perlakuan awal selanjutnya disterilisasi dengan mesin ultraviolet (UV) dan ditampung sebagai AIR STERIL di dalam water tank.

6. Proses mixing 2. YACON dan AIR STERIL dicampur di mesin blending. Tahap selanjutnya yakni proses pembotolan dan pengepakan. Botol-botol polystyrene dihasilkan oleh mesin moulding. Mesin ini mampu menghasilkan 11.000 botol dalam sekali produksi. Yakult dibotolkan secara otomatis oleh mesin pengisi dengan takaran $65 \mathrm{ml}$ dan ditutup dengan aluminium foil. Yakult yang sudah dibotolkan akan dikemas menjadi kemasan multi yang terdiri dari 5 botol/pak dan dikemas menjadi kemasan repack yang terdiri dari 10 pak multi (50 botol). Yakult yang sudah dikemas akan disimpan dalam cold storage. Botol yakult kemasan repack akan dibedakan menjadi dua jenis. Pertama dengan tutup kemasan bening yang akan didistribusi-kan langsung di pasaran. Kedua yakni kemasan dengan tut up plastik biru. Kemasan ini akan menjadi stock distribusi yang dilakukan oleh yakult lady.

Dalam berita yang termuat di surat kabar online Surya, Director Marketing Communication and Commercial PT Yakult Indonesia Persada Antonius Nabanan 
mengatakan, pabrik di Mojokerto akan dapat memproduksi yakult 65 mililiter dengan jumlah produksi sebanyak 610 ribu botol per hari.

\section{DISTRIBUSI}

Ada dua cara distribusi yakult:

1. Yakult Lady

Yakult lady adalah para ibu rumah tangga yang terlebih dahulu dibimbing untuk menjalankan misi mengirimkan Yakult dengan kualitas terbaik dimanapun dan kapanpun. Sistem ini melayani pengiriman Yakult kepada pelanggan walau hanya 1 botol saja. Yakult repack dengan kemasan tutup plastik biru yang disimpan di cold storage digunakan untuk distribusi melalui yakult lady. Yakult lady juga melakukan komunikasi dan memberikan informasi kesehatan kepada pelanggan, sehingga yakult lady disebut pula sebagai Pusat Informasi Berjalan. Yakult yang didistribusikan diletakkan dalam sebuah box khusus yang mampu menjaga suhu dingin.

\section{Direct Sales}

Direct sales menjamin ketersediaan yakult di seupermarket, minimarket, toko, kantin, dan gerai lainnya. Direct sales melayani pendistribusian ke tempat penjualan yakult dalam skala besar, bukan ecer. Pendistribusian dari pabrik ke tempat-tempat tujuan dilakukan menggunakan kendaraan berpendingin ke seluruh wilayah yang tersebar di seluruh pulau Jawa, Madura, Bali, Lombok, Sumatera, Batam, Bangka, Kalimantan, dan Sulawesi. Pada tempat distribusi akan disediakan lemari pendingin untuk menjual yakult. Yakult yang dijual di pasaran haruslah dalam keadaan dingin. Suhu yang dingin akan mempertahankan bakteri baik hidup. Jika Yakult di jual tidak dalam suhu dingin atau Yakult hanya disimpan di suhu ruangan, maka kualaitas dari minuman prebiotik akan menurun.

Produk minuman kesehatan yakult sangat sensitif terhadap temperatur. Perubahan temperatur sangat berpengaruh terhadap bakteri Lactobacillus casei Shirota strain yang terdapat dalam minuman yakult. Bakteri Lactobacillus casei harus dipertahankan hidup, karenanya harus diusahakan agar setelah dibotolkan, bakteri-bakteri tersebut tidak lagi melakukan proses fermentasi. Untuk itu yakult 
harus selalu disimpan didalam pendingin (dibawah $10^{\circ} \mathrm{C}$ ) karena penyimpanan didalam pendingin akan menjaga bakteri yakult tetap non aktif.

\section{KESIMPULAN}

Yakult merupakan pelopor minuman prebiotik yang mengandung bakteri Lactobacillus casei Shirota strain dengan manfaat membantu usus dalam menekan pertumbuhan bakteri sehingga usus kita selalu berfungsi dengan baik.Produk yakult dipasarkan dengan dua sistem, yaitu sistem yakult lady dan direct sales.Yakult terus melakukan inovasi untuk mengembangkan mutu produk yang membantu menjaga kesehatan usus seluruh kalangan masyarakat.

Penelitian ini memberikan kontribusi saran diantaranya: Bagi mahasiswa disarankan untuk lebih aktif dalam kegiatan perkuliahan dan menulis serta membaca. Bagi dunia perusahaan khususnya para pengembang perusahaan diharapkan mampu meningkatkan kegiatan produksinya dan selalu menjaga mutu produk supaya lebih banyak pembeli dan pemasarannya lebih meluas.

\section{DAFTAR PUSTAKA}

Arief, Yudantho. . Analisis Strategi Pengembangan Produk Smart Panin Pada PT. Panin Bank,Tbk. Skripsi: Universitas Diponegoro Semarang,2013

Buchari, Alma. Manajemen Pemasaran dan Pemasaran Jasa. Bandung: Alfabeta, 2008

Kasali, Rhenald. Membidik Pasar Indonesia Segmentating, Targeting, Positioning. Jakarta: Gramedia Pustaka Utama, 2001

Kotler, Philip \& Amstrong. Dasar-Dasar Pemasaran. Jakarta: PT.Index Kelompok Gramedia,2004

Kotler, Philip dan Keller. Manajemen Pemasaran. Bogor: Ghalia Indonesia.2002

Muhandri. T. dan D. Kadarisman. . Sistem Jaminan Mutu Pada Industri Pangan. Edisi Kedua. Bogor: IPB Press.2008

Tjiptono, Fandy. . Strategi Pemasaran. Edisi Ketiga. Bandung: ANDI, 2008

Triton PB. 2008. Marketing Strategic. Yogyakarta : Tugu Publisher.,2008

Widodo, D. Imam. Perencanaan dan Pengembangan Produk : Product, Planning \&Design. Yogyakarta: UII Press Indonsia, 2003 
AL-'ADALAH: Jurnal Syariah dan Hukum Islam

Hal. 41-52

http://www.yakult.co.id

http://ptyakultindonesia.blogspot.co.id/p/profil.html
e-ISSN: 2503-1473

Vol. 1, No. 1, Maret 2016 